\title{
A Case of Sudden Posterior Reversible Encephalopathy Syndrome (PRES) in a 32 Year Old with a Twin Pregnancy
}

\author{
Maria Petra Agius*, Nicholas Felice, Maria Mallia and Muscat Baron \\ Department of Obstetrics and Gynaecology, Mater Dei Hospital, Malta
}

Submission: March 16, 2017; Published: May 03, 2017

*Corresponding author: Maria Petra Agius, Department of Obstetrics and Gynaecology, Mater Dei Hospital, Malta, Email: mariapetra.agius@gmail.com

\section{Introduction}

Posterior reversible encephalopathy syndrome (PRES) requires neurological and radiological input for diagnosis. Clinical features include a headache, encephalopathy, seizures and visual disturbances. Radiological findings suggestive of PRES on MRI, are symmetrical vasogenic oedema involving the sub-cortical white matter in the parieto-occipital, posterior temporal and posterior frontal lobe. The pathophysiology involves failure of cerebral auto-regulation in particular in the posterior circulation of the brain, causing vasospasm and reversible cerebral ischaemia. Pre-eclampsia is one of the commonest causes of PRES, and moreover, Studies have shown that pregnancy alone predisposes the brain to the neurological complications of eclampsia by promoting hydrostatic brain oedema when blood pressure is acutely elevated.

\section{Case Summary}

A 32 year old primagravida, presented at $27+3$ weeks gestation with hypertension $(204 / 129 \mathrm{mmHg})$, proteinuria (4+), severe headaches, vomiting and loss of vision. She was admitted to labour ward and started on dexamethasone, intravenous hydralazine and magnesium sulphate. Neurological examination revealed hyper-reflexia and 3 beats of clonus. MRI head showed bilateral hyperintensities in the parieto-occipital regions affecting the cortex and subcortical white matter together with petechial haemorrhages in the occipital lobe, suggestive of PRES. After 4 hours of continuous monitoring, the blood pressure and patient's symptoms did not improve and she was consented for an emergency lower segment caesarean section. Both infants weighing $560 \mathrm{~g}$ and $850 \mathrm{~g}$ were transferred to neonatal intensive care unit, whilst the mother was kept in tubated and managed in an intensive care unit. Her vision recovered

After 24 hours and her blood pressure was reduced by labetalol and nifedipine. However, proteinuria persisted and her blood pressure control was still sub-optimal. She was discharged 12 days later on calcium channel blockers and followed up by a nephrologist. One of the infants died of severe necrotising enterocolitis.

\section{Conclusion}

Making an early diagnosis and providing adequate monitoring and necessary treatment is crucial to both mother and fetus. The cerebral insult in PRES is reversible and a high index of suspicion is required to prevent long-term complications associated with the condition.

When PRES is associated with pre-eclampsia, management follows the treatment algorithm for severe pre-eclampsia with blood pressure control, prevention and/or treatment of seizures. 
This work is licensed under Creative Commons Attribution 4.0 Licens DOI: $10.19080 / J G W H .2017 .04 .555641$
Your next submission with Juniper Publishers will reach you the below assets

- Quality Editorial service

- Swift Peer Review

- Reprints availability

- E-prints Service

- Manuscript Podcast for convenient understanding

- Global attainment for your research

- Manuscript accessibility in different formats ( Pdf, E-pub, Full Text, Audio)

- Unceasing customer service

Track the below URL for one-step submission https://juniperpublishers.com/online-submission.php 